Original Contribution

\title{
EFFECT OF FOLIAR APPLICATION OF AMINO ACID AND CALCIUM CHELATE ON SOME QUALITY AND QUANTITY OF GOLDEN DELICIOUS AND GRANNY SMITH APPLES
}

\author{
M. Arabloo ${ }^{1}$, M. Taheri ${ }^{1}$, H. Yazdani ${ }^{2}$, M. Shahmoradi ${ }^{3 *}$ \\ ${ }^{1}$ Department of Horticultural Science, College of Agriculture, Azad University of Abhar, Iran \\ ${ }^{2}$ Department of Horticultural Science, College of Agriculture, Azad University of Shirvan, Branch, \\ Iran \\ ${ }^{3}$ Department of Horticultural Science, College of Agriculture, Shiraz University, Shiraz, Iran
}

\begin{abstract}
In order to investigate the effects of foliar application of amino acid and calcium chelate on 'Golden Delicious' and 'Granny smith' apple trees, a randomized complete block design with four repetitions was conducted. Apple trees were sprayed with $\left(0,2,4 \mathrm{mg} \mathrm{L}^{-1}\right)$ of amino acid and $\left(0,2,4 \mathrm{mg} \mathrm{L}^{-1}\right)$ calcium chelate and their combination. Fruit weight, fruit firmness, total soluble solids, titretable acidity and calcium content of fruits were determined. All the applied treatments significantly increased quality and quantity traits compared to the control trees in both cultivars. The combination of amino acid and calcium chelate increased weight of both cultivars. Thus, in this study combination of amino acid and calcium chelate foliar spray treatment could be recommended from results as they significantly increased quality and quantity traits of 'Golden delicious' and 'Granny smith' apple trees.
\end{abstract}

Key words: apple, amino acids, calcium, foliar application

\section{INTRODUCTION}

Apple fruit is well characterized for their taste, flavor and dietary values. It is one of the genera of pome fruit trees of the temperate zones belonging to the Rosaceae family and is one of the most important garden crops and due to its high adaptability and it is one of the most extensively fruit trees cultivated in temperate zones (1). Health and superior quality of fruit as one of the most crucial organs of the trees is in direct relation with health of humans (1). Apple storability and quality in large extent is determined by the genotype of the cultivars. Some other factors may influence expression of this peculiarity. The role of balanced nutrition on fruit storability is well known $(2,3)$. Adequate nutrition ensures a balance in fruit mineral composition (3). Calcium is an important nutrient element, which can affect apple quality after harvest. Calcium deficiency expresses itself in the form of cork spot, which develop primarily during the early part of the growing season, bitter pit, which develops during the latter part of the growing season, and senescent breakdown, which forms during

\footnotetext{
*Correspondence to: M. Shahmoradi,

Department of horticultural sciences, college of Agriculture, Shiraz University. Shiraz. Iran, Email: shahmoradim31@gmail.com
}

and after storage $(4,5)$. Calcium provides cell wall rigidity by cross-linking of pectic chains of the middle lamella (6). Disintegration of cell walls and the collapse of affected tissues are typical symptom of calcium deficiency (5). The proportion of calcium pectate in cell walls is very important for the ripening of fruit. The increase of fruit calcium content leads to the increase fruit firmness of fruit and delays fruit ripening or prevents calcium-related disorders $(4,7,8)$. Increases in calcium concentration both in fruit flesh and skin have been found in 'Jonathan' apples (9) and always, the increase in concentration in the peel was far greater than in the pulp. Several authors $(9,10,11)$ have reported changes in fruit quality traits, particularly flesh firmness, acids and color, associated with increases of calcium concentration in the pulp of fruits. Calcium accumulation in apples is influenced by different management practices and ecological conditions (12). Experimental results indicated different effects of applying calcium fertilizers $(13,14)$. In most part of the world, pre-harvest calcium treatment is generally effective in increasing fruit calcium and reducing spoilage $(15$, 16). The favorable effect of calcium obtained by Siddiqui and Bangerth (17) on 'Golden Delicious' apples, suggested that the observed effects of $\mathrm{CaCl}_{2}$ on fruit firmness are likely to be associated with the calcium 
content of the covalently-bound pectin fractions. When they are applied as inorganic salts to the growing medium, above $\mathrm{pH} 6, \mathrm{Fe}$, and above $\mathrm{pH} 7 \mathrm{Mn}, \mathrm{B}, \mathrm{Cu}$ and $\mathrm{Zn}$ have become insoluble forms, so their absorption by the plants has decrease. However chelates are obtained by the reaction of metallic salts with their synthetic or natural organic complexes has saved the metal cations from undesirable reactions such as precipitation $(5,7)$. For this reason synthetic precursor which has the ability of making strong chelate is almost used in plant growing medium. EDTA (ethylene diamine tetra acetic acid) and EDDHA (ethylene diamino-hydroxyphenylacetic acid) are well known as synthetic precursors. However, because of the disadvantages mentioned above it has been suggested that micro elements as inorganic or organic complexes should be applied to the leaves instead of adding them to the growing medium in order to solve micro element requirements of the plants $(5,7)$. The leaf fertilizers which an inorganic mineral structure hardly diffuses from the leaf surface into the plant because of high weight molecular structure. In order to eliminate these negative effects leaf fertilizers with organic structure as synthetic chelates were developed. Foliar fertilizers as chelate should be easily absorbed by the plants rapidly transported and should be easily release their ions to affect the plant (7). Natural chelators as mid molecular weight compounds like amino acids that have long organic chains diffuse easily to cell cytoplasm according to their chemical structure. These chelators are not phytotoxic to plants (4). They make complexes especially with heavy metals and prevent them to uptake by plants in higher ratio $(18,19)$. The purpose of this study was to investigate using foliar pre-harvest application of amino acid and calcium chelate on some fruit quantity and quality of 'Golden delicious' and 'Granny Smith'.

\section{MATERIAL AND METHODS}

The present study was performed on 'Golden delicious' and 'Granny smith' apple trees, budded on MM106 rootstock. All trees were almost uniform in vigor, grown in sandy soil under conventionally accepted practices, using drip irrigation system. A randomized complete block design with four repetitions was conducted in the city Zanjan, Iran. In this experiment, different concentrations $(0,2,4$ $\mathrm{mg} \mathrm{L}^{-1}$ ) of amino acid and calcium chelate and their combination were sprayed on the apple trees. The sprayings at once month intervals started after fruit set until harvest. Foliar sprays were applied using a hand pressure sprayer. Fruit samples were taken to the lab and stored in a refrigerator at $4{ }^{\circ} \mathrm{C}$ until analyses. Fifteen fruits from each replicate were randomly taken for determining the physical and chemical characteristics. Fruit weights $(g)$ were measured by electronic scale and fruit firmness was measured on two opposite faces of the equatorial zone using a texture analyzer (Stevens-Lfra, Harlow, Essex, UK). The percentage of total soluble solids (TSS \%) was determined in fresh fruit juice using a hand refract meter (ATAGO, Tokyo, Japan) at $20^{\circ} \mathrm{C}$. The $\mathrm{pH}$ values were determined by using a pH meter (JENWAY 351, Staffordshire, UK). Total acidity (TA \%) was determined by titration with $0.3 \mathrm{~N} \mathrm{NaOH}$ up to $\mathrm{pH}$ 8.1. calcium was measured by atomic absorption spectrometry (Z8000; Hitachi Ltd., Tokyo, Japan). Results of the measured parameters were subjected to computerized statistical analysis using MSTAT package for analysis of variance (ANOVA) and means of treatments were compared using LSD at 0.05 .

\section{RESULTS AND DISCUSSION}

Figure 1 shows that, the direct effect of $4 \mathrm{mg}$ $\mathrm{L}^{-1}$ amino acids+ $4 \mathrm{mg} \mathrm{L}^{-1}$ calcium chelate foliar spray produced the highest significant fruit weight as it resulted in $54.9 \mathrm{~g}$ in 'Granny smith'. Meanwhile this treatment shows no significant difference with $4 \quad \mathrm{mg} \mathrm{L} \mathrm{L}^{-1}$ amino acids+2 and 0 calcium chelate on 'Granny smith'. A similar response was also evident on the effects of foliar $4 \mathrm{mg} \mathrm{L}^{-1}$ amino acids+ $4 \mathrm{mg} \mathrm{L}^{-1}$ calcium chelate on 'Golden delicious'. The lowest significant fruit weights were observed in the control trees. Spraying of amino acids and calcium chelate significantly increased the average of fruit weight of 'Golden delicious' and 'Granny Smith' fruits compared with control tress. Texture of the apple fruit is an important factor for the acceptability of the product by the consumer (20). The general positive effects of amino acid foliar spray applications could be attributed to enhanced pollen tube ovule penetration and delayed ovule senescence which increases fruit set and yield. Similar findings were reported on pear (21, 22). Data in Figure $\boldsymbol{2}$ indicated that the fruit firmness of 'Golden delicious' was significantly affected by foliar spraying of $2 \mathrm{mg} \mathrm{\textrm {L } ^ { - 1 }}$ calcium chelate as compared with control and 'Granny smith' apples. The fruit firmness increased with $2 \mathrm{mg} \mathrm{L}^{-1}$ calcium chelate from 5.13to $6.83 \mathrm{Kg} / \mathrm{cm}^{2}$ in 'Golden delicious' apple. Also, Benavides et al. (15) on 'Golden Smoothee' apple found that the fruit firmness increased when calcium was applied. Similar results were obtained by Casero et al. (23) on 'Golden Smoothee' apple who indicated that fruit firmness shows a positive correlation with fruit calcium content and bitter pit incidence correlates negatively with this nutrient concentration. Furthermore, Saure (24) on fleshes fruit reported that calcium is known to stabilize cell membranes and in this way may prevent physiological 
disorders attributed to calcium deficiency. $2 \mathrm{mg} \mathrm{L} \mathrm{L}^{-1}$ amino acid $+2 \mathrm{mg} \mathrm{\textrm {L } ^ { - 1 }}$ calcium chelate as foliar spray had a positive significant effect on total soluble solids (TSS \%) as compared with the control treatments in 'Golden delicious'.

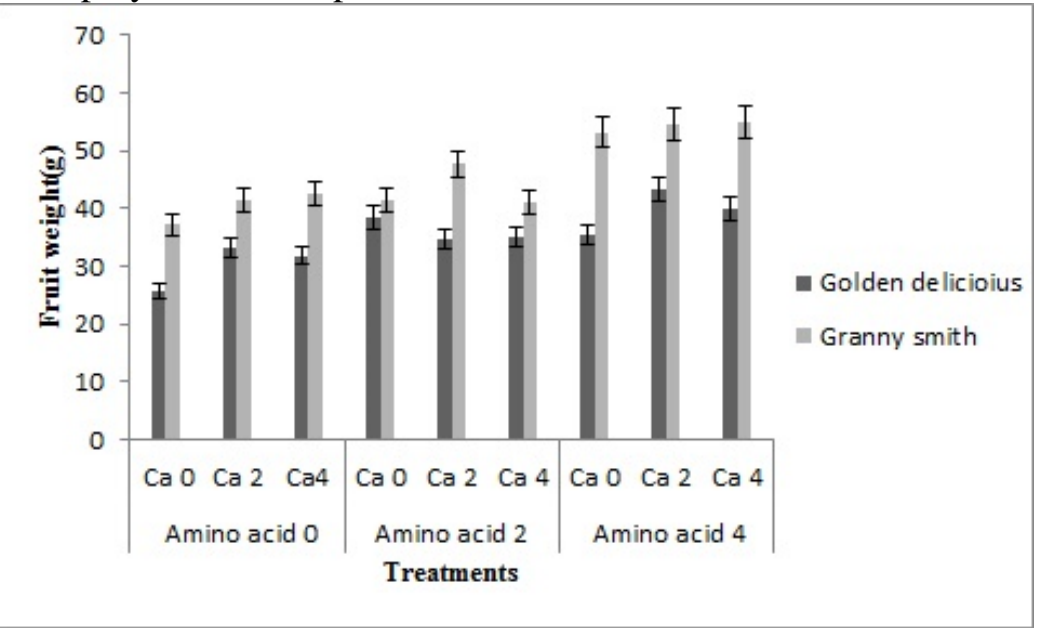

Figure 1. Effects of foliar application of amino acid and calcium chelate on the average of fruit weight. Vertical bars are standard deviations (SD) of means.

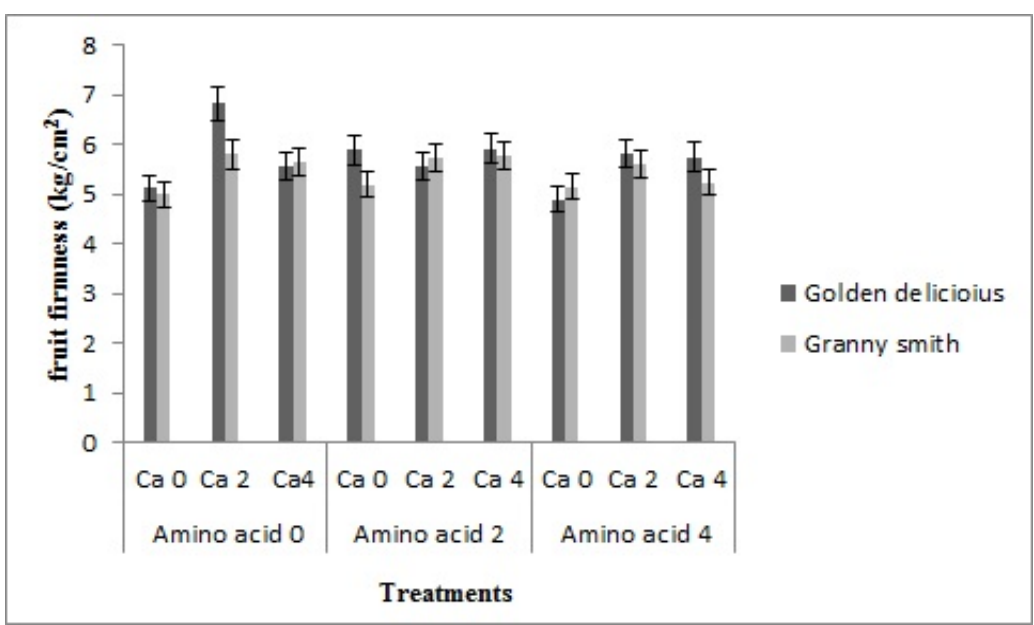

Figure 2. Effects of foliar application of amino acid and calcium chelate on the fruit firmness. Vertical bars are standard deviations (SD) of means.

Whereby these values were not significantly higher than those obtained in the treatments with $2 \mathrm{mg} \mathrm{L}^{-1}$ amino acid $+0 \mathrm{mg} \mathrm{\textrm {L } ^ { - 1 }}$ calcium chelate, $2 \mathrm{mg} \mathrm{L}^{-1}$ amino acid $+4 \mathrm{mg} \mathrm{L}^{-1}$ calcium chelate, 0 $\mathrm{mg} \mathrm{L}^{-1}$ amino acid $+4 \quad \mathrm{mg} \mathrm{L}^{-1}$ calcium chelate and $4 \mathrm{mg} \mathrm{L}^{-1}$ amino acid $+4 \mathrm{mg} \mathrm{L}^{-1}$ calcium chelate. No significant differences were observed among the values of TSS obtained for 'Granny smith' (Figure 3).

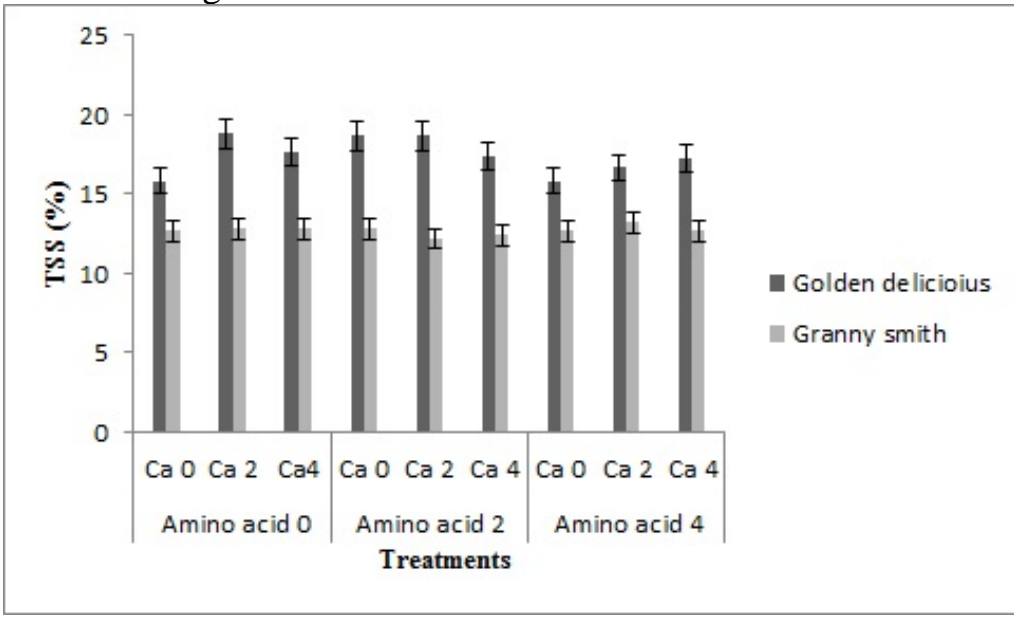

Figure 3. Effects of foliar application of amino acid and calcium chelate on the total soluble solids. Vertical bars are standard deviations (SD) of means. 
Amino acid at $4 \mathrm{mg} \mathrm{L}^{-1}+$ calcium chelate at $2 \mathrm{mg} \mathrm{L}^{-1}$ significantly increased TA\% of 'Granny smith' apple fruit as compared with the control and 'Golden delicious'. Whereby these values were not significantly higher than those obtained in the treatments with 0 amino acid+4 $\mathrm{mg} \mathrm{L}^{-1}$ calcium chelate. while, the lowest value was obtained by the 0 amino acid $+2 \mathrm{mg} \mathrm{L}^{-}$ ${ }^{1}$ calcium chelate and $4 \mathrm{mg} \mathrm{L}^{-1}$ amino acid +0 calcium chelate on 'Golden delicious' apples (Figure 4).

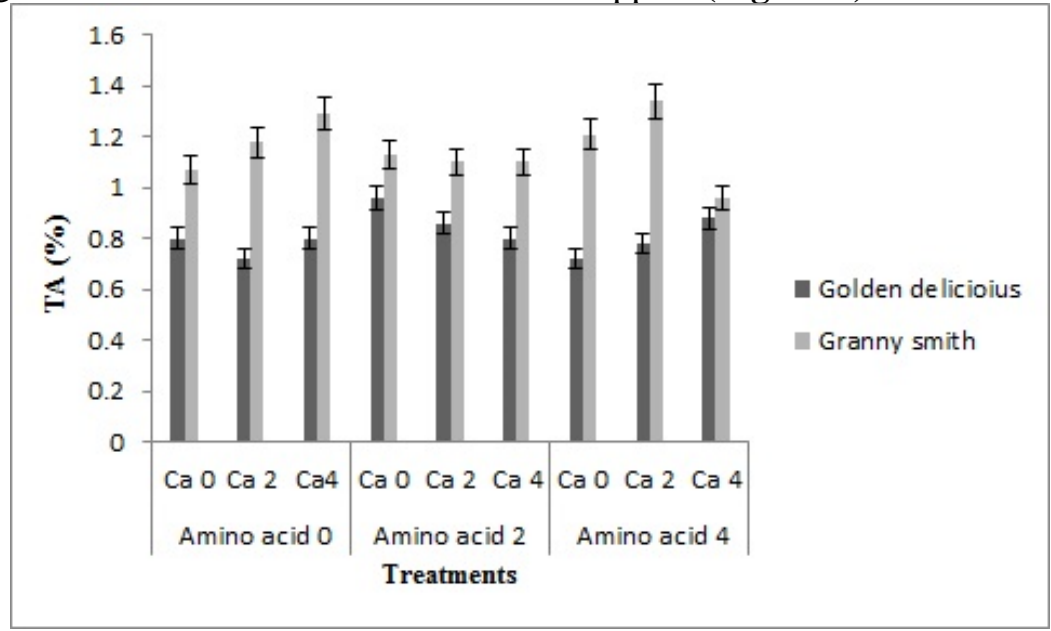

Figure 4. Effects of foliar application of amino acid and calcium chelate on the TA.

Vertical bars are standard deviations (SD) of means

No significant differences were found in $\mathrm{pH}$ in both cultivars in all of the treatments (Figure 5). Differences in calcium content were statistically significant among treatments for both cultivars. The calcium content in 'Golden delicious' apples analyzed at harvest time ranged between 18 and $52 \%$ of dry matter.

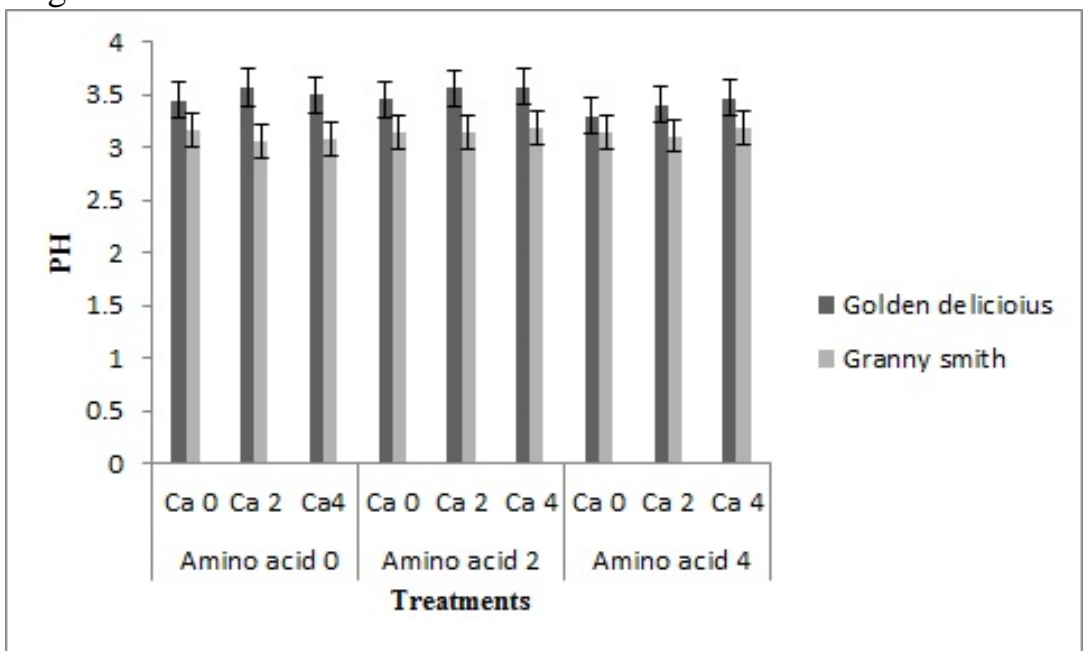

Figure 5. Effects of foliar application of amino acid and calcium chelate on the $\mathrm{pH}$.

Vertical bars are standard deviations (SD) of means.

Foliar application of 0 amino acid $+4 \mathrm{mg}$ $\mathrm{L}^{-1}$ calcium chelate and $4 \mathrm{mg} \mathrm{L}^{-1}$ amino acid+2 $\mathrm{mg} \quad \mathrm{L}^{-1} \quad$ calcium chelate significantly increased the calcium content in 'Golden delicious' fruits. The highest calcium content was provided in 'Golden delicious' apples than 'Granny smith' apples (Figure 6). Pre harvest calcium treatments used to increase the calcium content of the cell walls of fruit tissue after harvest. Moreover, it is effective in delaying senescence, resulting in firmer, higher quality fruit (25). The beneficial effect of calcium chloride could be attributed to the physiological role of calcium which plays a binding role in the complex polysaccharides and proteins forming the cell wall (26). Our results are in agreement with those recorded by Asgharzade et al. (20) and Casero et al. (23) they reported that the enhancement occurred in fruit quality due to foliar application of calcium could be attributed to the effect of calcium in enhancing and 
advancing flowering, maturity and the translocation of carbohydrates from leaves to fruits. Benavides et al. (15) applied preharvest calcium treatment, 6 or 12 times at rate of $1 \%(\mathrm{w} / \mathrm{v})$ beginning 60 days after full bloom. The results showed that the calcium applications were equally effective on increasing the calcium content in the fruit. Increases in calcium concentration both in fruit flesh and skin have been found in 'Jonathan' apples (9) and always, the increase in concentration in the peel was far greater than in the pulp. Increases in the concentrations of other mineral elements in fruit flesh and skin were also noted by Kadir (9). In addition Jafarpour and Poursakhi (27) stated that calcium application in summer or in autumn increased fruit calcium concentration but their effect was weaker than summer plus autumn calcium applications. The above results are in line with findings found by Wang et al. (28) on 'Golden Delicious' apples who indicated that calcium and polyamines may be competing for the same binding sites in cell wall. In addition, the improvement of fruit quality during storage by these actions could involve strengthening of the cell wall.

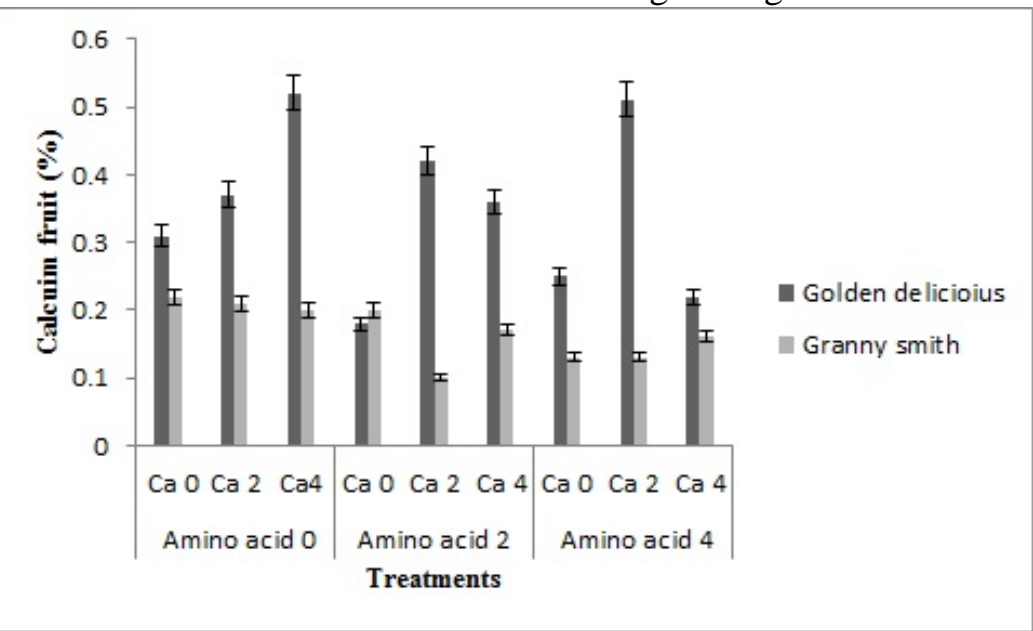

Figure 6. Effects of foliar application of amino acid and calcium chelate on the calcium fruit. Vertical bars are standard deviations (SD) of means.

\section{CONCLUSION}

It can be concluded from results of the present study that combination of amino acid and calcium chelate treatments significantly improved fruit quality of 'Granny smith' and 'Golden delicious' apples tress. Consequently they are recommended to be effectively applied in the under same conditions.

\section{REFERENCE}

1. Asgharzade, A., Babaeian, M., Foliar application of calcium borate and micronutrients effects on some characters of apple fruits in Shirvan region. Ann Biol Res, 3 (1):527-533, 2012.

2. Dris, R., Nikanen, R., Fallahi, E., Nitrogen and calcium nutrition and fruit quality of commercial apple cultivars grown in Finland. J. Plant Nut, 21: 2389-2402, 1998.

3. Terblanche, I.H., Gurgen, K.H., Hesebeck, I., An integrated approach to orchard nutrition and bitter pit control. Acta Hort, 92: 71-82, 1980.

4. Ferguson, I., Drobak, R., Calcium and the regulation of plant growth and senescence. Hort Sci, 23: 262-266, 1988.
5. Marschner, H., Mineral nutrition of higher plants. Academic Press, London. 1995.

6. Glenn, G.M., Reddy, A.S.N., Poovaiahb, W., Effect of calcium on cell wall structure, protein phosphorylation and protein profile in senescence apples. Plant Cell Physiol, 24: 565-573, 1988.

7. Zocchi, G., Mignani, I., Calcium physiology and metabolism in fruit trees. Acta Hort, 383: 15-20, 1995.

8. Salehi, M., Abutalebi, A.H., Mohammadi, A.H., Effect of Foliar Application of Amino Calcium on Fruit Firmness and Storage life of Golden Delicious Apples. Life Sci. J, 10: 140-142,2013.

9. Kadir, S.A., Fruit quality at harvest of 'Jonathan' apple treated with foliar-applied calcium chloride. J. Plant Nut, 27: 19912006, 2004.

10.Raese, J.T., Drake, S.R., Effects of pre harvest calcium sprays on apple and pear quality. J. Plant Nut, 16: 1807-1819, 1993.

11.Neilsen, G., Neilsen, D., Dong, S., Toivonen, P., Peryea, F., Application of $\mathrm{CaCl}_{2}$ sprays earlier in the season may reduce bitter pit incidence in 'Braeburn' apple. Hort Sci, 40: 1850-1853, 2005. 
12.Tomala, K., Orchard factors affecting fruit storage quality and perediction of harvest date of apples. Acta Hort, 485: 373-382, 1999.

13.Tomala, K., Effects of calcium sprays on storage quality of Sampion apples. Acta Hort, 448: 59-66, 1997.

14.Wojcik, P., Yield and Jonagold apple fruit quality as influenced by spring sprays commercial material containing calcium and boron. J. Plant Nut, 25: 999-1000, 2002.

15.Benavides, A., Recasens, I., Casero, T., Soria, Y., Puy, J., Multivariate analysis of quality and mineral parameters on Golden Smoothee apples treated before harvest with calcium and stored in controlled atmosphere. Food Sci. Technol. Int, 8: 139145, 2002.

16.Neilsen, G., Neilsen, D., Effect of foliar Zn, form and timing of sprays on fruit $\mathrm{Ca}$ concentration in new apple cultivars. Acta Hort, 594: 435-443, 2002.

17.Siddiqui, S., Bangerth, F., Effect of preharvest application of calcium on flesh firmness and cell-wall composition of apples. Influence of fruit size. J. Hort. Sci, 70: 263-269, 1995.

18.Fayek, M.A., Yehia, T.A., El-Fakhrany, E.M.M., and Farag, A.M., Effect of Ringing and Amino Acids Application on Improving Fruiting of Le Conte Pear Trees. J. Hort. Sci. Ornamental Plants, 3 (1): 01$10,2011$.

19.Molaie, H., Panahi, B., Tajabadipour, A., The effect of foliar application of some amino acid compounds on photosynthesis and yield of two commercial cultivars in pistachio orchards of Kerman province in Iran. Inter. J. Agri. Crop Sci, 23:28272830, 2013.

20.Asgharzade, A., Valizade, G.A., and Babaeian, M., Effect of Calcium Chloride $\left(\mathrm{CaCl}_{2}\right)$ on some quality characteristic of apple fruits in Shirvan region. Afri. J. Microbiol. Res, 6(9): 2000-2003, 2012.
21.Crisosto, C.H., Lombard, P.B., Richardson, D.G., and Tetley, R., Putrescine extends effective pollination period in Comice pear (Pyrus communis L.) irrespective of postanthesis ethylene levels. Sci. Hort, 49: 211221, 1992.

22.Franco-Mora, O., Tanabe, K., Tamura, F., and Itai, A., Effect of putrescine application on fruit set in Housui Japanese pear (Pyrus pyrifplia Nakai). Sci. Hort, 104: 265-273,2005.

23.Casero, T., Benavides, A., Puy, J., Recasens, I., Relationships between leaf and fruit nutrients and fruit quality attributes in Golden Smotthee apples using multivariate regression techniques. J. Plant Nut, 27: 313-324, 2004.

24.Saure, M.C., Calcium translocation to fleshy fruit: Its mechanism and endogenous control. Sci. Hort, 105: 65-89,2005.

25.Chardonnet, C.O., Charron, C.S., Sams, C.E., Conway, W.S., Chemical changes in the cortical tissue and cell walls of calciuminfiltrated "Golden Delicious" apple during storage. Postharvest Biol. Tech, 28:97-111, 2003.

26.Khalifa, R.KH.M., Omaima, M. H., AbdEl-Khair, H., Influence of foliar spraying with boron and calcium on productivity, fruit quality, nutritional status and controlling of blossom end rot disease of Anna apple trees. World. J. Agri. Sci, 5(2):237-249, 2009.

27.Jafarpour, M., Poursakhi, K., Study of concurrent effect of using nutrients through soil and foliar application on yield and quality of the "Red Delicious" apple. International Conference on Life Science and Technology. IPCBEE vol.3 IACSIT Press, Singapore, pp 87-96, 2011.

28.Wang, C.Y., Conway, W.S., Abbott, J.A., Kramer, G.F., Sams, C.E., Postharvest infiltration of polyamines and calcium influences ethylene production and texture changes in 'Golden Delicious' apples. $J$. Am. Soc. Hort. Sci, 118: 801-806, 1993. 